Charles M. Haberkern MD, Anne M. Lynn MD, Jeremy M. Geiduschek MD, Mary Kay Nespeca RN, Lawrence E. Jacobson MD, Susan L. Bratton MD, Maureen Pomietto RN MN

\section{Epidural and intrave- nous bolus morphine for postoperative analgesia in infants}

Purpose: To compare two doses of bolus epidural morphine with bolus iv morphine for postoperative pain after abdominal or genitourinary surgery in infants.

Methods: Eighteen infants were randomly assigned to bolus epidural morphine $\left(0.025 \mathrm{mg} \cdot \mathrm{kg}^{-1}\right.$ or $\left.0.050 \mathrm{mg} \cdot \mathrm{kg}^{-1}\right)$ or bolus iv morphine (0.050-0.150 $\left.\mathrm{mg} \cdot \mathrm{kg}^{-1}\right)$. Postoperative pain was assessed and analgesia provided, using a modified infant pain scale. Monitoring included continuous ECG, pulse oximetry, impedance and nasal thermistor pneumography. The $\mathrm{CO}_{2}$ response curves and serum morphine concentrations were measured postoperatively.

Results: Postoperative analgesia was provided within five minutes by all treatment methods. Epidural groups required fewer morphine doses $(3.8 \pm 0.8$ for low dose [LE], $3.5 \pm 0.8$ for high dose epidural [HE] vs. $6.7 \pm 1.6$ for iv, $P<0.05$ ) and less total morphine $\left(0.11 \pm 0.04 \mathrm{mg} \cdot \mathrm{kg}^{-1}\right.$ for $L E, 0.16 \pm 0.04$ for $H E$ vs $0.67 \pm 0.34$ for $i v, P<0.05$ ) on PODI. Dose changes were necessary in all groups for satisfactory pain scores. Pruritus, apnoea, and haemoglobin desaturation occurred in all groups. $\mathrm{CO}_{2}$ response curve slopes, similar preoperatively (range $36-41 \mathrm{ml} \cdot \mathrm{min}^{-1} \cdot \mathrm{mmHg} \mathrm{ETCO}{ }^{-1} \cdot \mathrm{kg}^{-1}$ ) were generally depressed (range, $16-27 \mathrm{ml} \cdot \mathrm{min}^{-1} \cdot \mathrm{mmHg}$ $\mathrm{ETCO}_{2}{ }^{-1} \cdot \mathrm{kg}^{-1}$ ) on PODl. Serum morphine concentrations,

\section{Key words}

PAIN: postoperative;

ANAESTHESIA: paediatric;

ANALGESIA: epidural, intravenous, morphine, postoperative.

From the Department of Anesthesiology, University of Washington School of Medicine and Department of Anesthesia and Critical Care, Children's Hospital and Medical Center, Seattle, WA.

Address correspondence to: Dr. Charles M. Haberkern, Children's Hospital and Medical Center, PO Box 5371, Seattle, WA 98105.

Phone: (206) 526-2518. Fax: (206) 527-3935.

e-mail: cmh@u.washington.edu

Supported by BRSG Grant \#RR05655-20.

Accepted for publication July 20, 1996. negligible in $L E\left(<2 \mathrm{ng} \cdot \mathrm{ml}^{-1}\right)$, were similar in the $H E$ and iv groups (peak $8.5 \pm 12.5$ and $8.6 \pm 2.4 \mathrm{ng} \cdot \mathrm{ml}^{-1}$, respectively). Conclusion: Epidural and iv morphine provide infants effective postoperative analgesia, although side effects are common. Epidural morphine gives satisfactory analgesia with fewer doses (less total morphine); epidural morphine 0.025 $m g \cdot \mathrm{kg}^{-1}$ is appropriate initially. Infants receiving epidural or iv morphine analgesia postoperatively need close observation in hospital with continuous pulse oximetry.

Objectif: Comparer deux doses épidurales de morphine en bolus avec un bolus de morphine iv administrées pour la douleur postopératoire après une chirurgie abdominale ou urogénitale chez l'enfant.

Méthodes: Dix-huit enfants ont été répartis pour recevoir soit un bolus de morphine épidural $\left(0,025 \mathrm{mg} \cdot \mathrm{kg}^{-1}\right.$ ou 0,05 $\left.\mathrm{mg} \cdot \mathrm{kg}^{-1}\right)$ soit un bolus de morphine iv $\left(0,050-0,150 \mathrm{mg} \cdot \mathrm{kg}^{-1}\right)$. La douleur postopératoire était évaluée et l'analgésie pourvue sur la base d'une échelle de douleur modifée pour la pédiatrie. Le monitorage incluait l'ECG continu, l'oxymétrie de pouls, la pneumographie par impédance avec un thermistor nasal. En postopératoire, on mesurait les courbes de réponse au $\mathrm{CO}_{2}$ 'et les concentrations sériques de morphine.

Résultats: L'analgésie postopératoire survenait en déçà de cinq minutes, indépendamment du traitement administré. Un nombre inférieur de doses de morphine $(3,8 \pm 0,8$ pour la dose légère $[D L], 3,5 \pm 0,8$ pour la dose forte $[D F]$ vs $6,7 \pm$ $1,6$ pour la morphine iv, $P<0,05)$ à demande a été requis pour les groupes recevant la morphine épidurale. Pour obtenir des scores satisfaisants sur l'échelle de la douleur, on a dû modifier les doses dans tous les groupes. On a noté du prurit, de l'apnée et une désaturation en oxygène dans tous les groupes. Les courbes identiques en préopératoire de la réponse au $\mathrm{CO}_{2}$ (écart, 36-4l $\mathrm{ml} \cdot \mathrm{min}^{-1} \cdot \mathrm{mmHg}$ $\mathrm{ETCO}_{2}^{-1} \cdot \mathrm{kg}^{-1}$ ) étaient généralement déprimées (écart, 16-27 $\left.\mathrm{ml} \cdot \mathrm{min}^{-1} \cdot \mathrm{mmHg} \mathrm{ETCO}_{2}^{-1} \cdot \mathrm{kg}^{-1}\right)$. Les concentrations de morphine sérique, négligeables pour $D L\left(<2 n g \cdot m l^{-1}\right)$, étaient identiques pour $D F$ et iv (maximum respectif $8,5 \pm 12,5$ et 8,6 $\left.\pm 1,4 n g \cdot m l^{-1}\right)$.

Conclusion: La morphine épidurale et la morphine iv procurent une analgésie postopératoire suffisante aux enfant malgré des effets secondaires fréquents. La morphine épidurale a 
produit une analgésie satisfaisante nécessitant moins de doses (dose totale moindre); la morphine épidurale $0,025 \mathrm{mg} \cdot \mathrm{kg}^{-1}$ est appropriée au début. Les enfants qui reçoivent de la morphine épidurale ou iv comme analgésique postopératoire doivent être surveillés de près à l'hôpital avec l'oxymétrie de pouls en continu.

Although intravenous morphine has been the mainstay of postoperative pain control in infants and children, epidural morphine has been shown to be effective. ${ }^{1-8}$ Infants may be at greater risk for respiratory depression associated with the use of intravenous and epidural morphine $^{8}$ than are children and adults. The pharmacokinetic behaviour of opioids ${ }^{9-11}$ is altered in neonates and young infants, ${ }^{12}$ and this may explain the increase in opioid-induced ventilatory depression. It is not known whether intravenous or epidural morphine is the more advantageous with respect to safety, efficacy, or clinical use in providing postoperative analgesia in infants.

This study was designed to compare the effectiveness, use, side effects, respiratory effects, and pharmacology of bolus epidural morphine in two doses with bolus intravenous morphine administered to infants for the control of postoperative pain following abdominal or genitourinary surgery.

\section{Methods}

After approval by the Institutional Human Subjects Review Board of Children's Hospital and Medical Center, ASA I and II infants aged 3-12 mo undergoing abdominal or genitourinary surgery were enrolled in this study after obtaining parental consent and were randomly assigned to one of three bolus treatment groups for control of postoperative pain: Group 1, epidural morphine $0.025 \mathrm{mg} \cdot \mathrm{kg}^{-1}$; Group 2, epidural morphine 0.050 $\mathrm{mg} \cdot \mathrm{kg}^{-1}$; Group 3, intravenous morphine 0.050-0.150 $\mathrm{mg} \cdot \mathrm{kg}^{-1}$. Perioperative management is described in Figure 1. Treatment was not blinded because it was considered unacceptable to place sham epidural catheters in infants in Group 3.

General anaesthesia was induced without premedication and maintained with a volatile anaesthetic and a neuromuscular blocking agent; no opioids or local anaesthetic agents were used intraoperatively. At the conclusion of the surgical procedure, a $20 \mathrm{~g}$ caudal epidural catheter (Burron ${ }^{\circledR}$ Medical Inc., Bethlehem, PA) was placed via an $18 \mathrm{~g}$ intravenous cannula (Terumo ${ }^{\circledR}$ Medical Corp., Elkton, MD) to a distance $<8$ $\mathrm{cm}$ from skin entry in those patients assigned to Groups 1 and 2, but not those in Group 3. All the infants' tracheas were extubated when the infants were awake, neuromuscular blockade had been reversed, and the end-

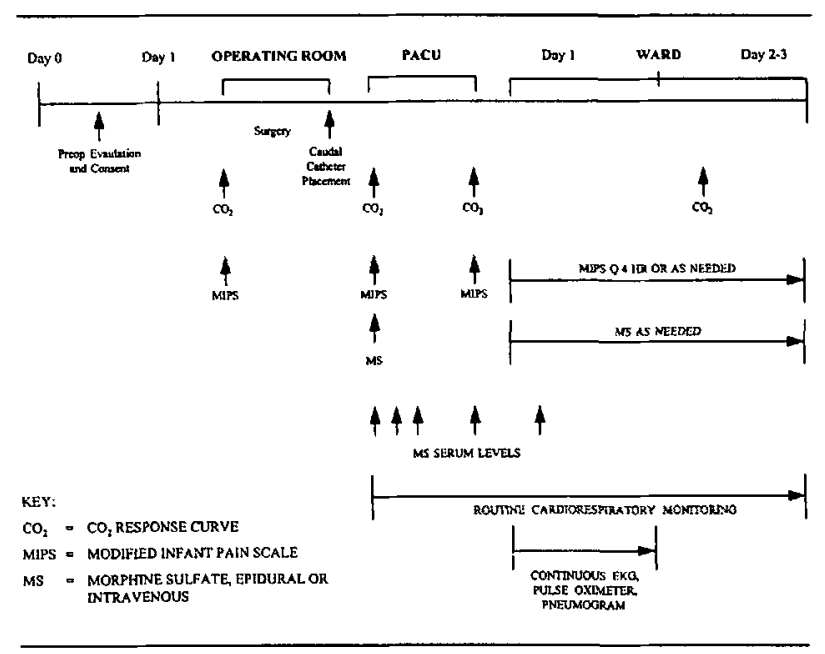

FIGURE 1 Protocol schema.

tidal concentration of volatile agent was $<0.2 \%$. Proper placement of the caudal catheter was confirmed in Group 1 and 2 infants by absence of anal wink following injection of $0.25 \mathrm{ml} \cdot \mathrm{kg}^{-1}$ lidocaine $1 \%$ with epinephrine $1: 200,000$.

After admission, vital signs were determined in the Post Anaesthesia Care Unit (PACU), the predetermined epidural morphine dose was administered to the infants in Groups 1 and 2, and intravenous morphine was administered in increments of $0.050 \mathrm{mg} \cdot \mathrm{kg}^{-1}$ in infants in Group 3 to achieve a pain scale score $>16$. Analgesia was assessed by the bedside nurse by a modification of the infant pain scales described by Barrier et al., and Grunau and Craig, ${ }^{13,14}$ a 20-point scale based on 10 observed characteristics (Figure 2).

Subsequent treatment was provided when the pain scale score was $<10$, and treatment was considered successful if a score $>16$ was obtained. In Groups 1 and 2 , rescue treatments with epidural morphine 0.025 $\mathrm{mg} \cdot \mathrm{kg}^{-1}$ and subsequent interval dose increases of $0.025 \mathrm{mg} \cdot \mathrm{kg}^{-1}$ were provided if the duration of analgesia was less than six hours; in Group 3, rescue and interval dose increases of $0.050 \mathrm{mg} \cdot \mathrm{kg}^{-1}$ were provided if analgesia lasted less than four hours. Morphine treatment doses were eliminated in Group 1, decreased by $0.025 \mathrm{mg} \cdot \mathrm{kg}^{-1}$ in Group 2, and decreased by 0.050 $\mathrm{mg} \cdot \mathrm{kg}^{-1}$ in Group 3 if side effects were considered excessive (i.e., frequent episodes of apnoea, bradycardia, and haemoglobin desaturation; sedation unresponsive to gentle stimulation; pruritus unresponsive to pharmacological intervention). Infants were maintained on the treatment regimen until the third postoperative day, oral analgesics were tolerated, or side effects warranted discontinuation of therapy.

All infants were monitored continuously in the post- 


\begin{tabular}{|c|c|c|c|c|c|}
\hline \multicolumn{6}{|c|}{ SCORE } \\
\hline & & 0 & 1 & 2 & Subtotal \\
\hline 1 & Sloep durlig & none & shor naps (5-10 & longer naps & \\
\hline 2 & 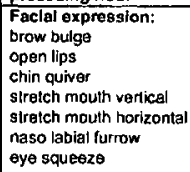 & marked & less marked & calm & \\
\hline 3 & Quality of eny & $\begin{array}{l}\text { screaming, } \\
\text { painful, high } \\
\text { pilched }\end{array}$ & $\begin{array}{l}\text { modulated } \\
\text { can be distracted }\end{array}$ & nacy & \\
\hline & & 0 & 1 & 2 & Subtotal \\
\hline 4 & Spontaneour motor & "thrashing, & moderate agitzlion & nombal & \\
\hline 5 & $\begin{array}{l}\text { Excitability and } \\
\text { rosponsivengeg io } \\
\text { stlmulatianton }\end{array}$ & $\begin{array}{l}\text { Tremulous, clonic } \\
\text { movements, Moro } \\
\text { reflex sponl. }\end{array}$ & $\begin{array}{l}\text { excessive reaclivity } \\
\text { to any stimulation }\end{array}$ & quiet & \\
\hline$\overline{6}$ & $\begin{array}{l}\text { Flaxion of fingers and } \\
\text { toas }\end{array}$ & $\begin{array}{l}\text { pronounced. } \\
\text { marked and } \\
\text { contan! }\end{array}$ & $\begin{array}{l}\text { less marked } \\
\text { intermilitent }\end{array}$ & absenl & \\
\hline & & & & 2 & Subtotal \\
\hline 7 & Sucking & $\begin{array}{l}\text { absent or } \\
\text { disorganized }\end{array}$ & $\begin{array}{l}\text { Intermititent (3 or } 4) \\
\text { slops wilh crying }\end{array}$ & $\begin{array}{l}\text { strong } \\
\text { inythic } \\
\text { pacines }\end{array}$ & \\
\hline$\overline{8}$ & Overallitine & strong hypertonicity & moderate & normal & \\
\hline 9 & Consolability & \begin{tabular}{|l|}
$\begin{array}{l}\text { none anter } 2 \\
\text { minutes }\end{array}$ \\
\end{tabular} & quiet afler i minute & 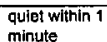 & \\
\hline 10 & 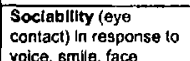 & absent & difficult to obtain & $\begin{array}{l}\text { easyy and } \\
\text { prolonged }\end{array}$ & \\
\hline & & \begin{tabular}{|l} 
Tolal Score \\
Total Possibite S \\
\end{tabular} & core: $z 0$ comfort & & \\
\hline
\end{tabular}

FIGURE 2 Modified infant pain scale (20 points for comfort). Infants were medicated for scores $<10$; scores $>16$ were considered adequate analgesia.

operative period with ECG, impedance pneumogram and pulse oximeter. In addition, for the first $24 \mathrm{hr}$ after surgery, all infants were monitored with continuous multi-channel recordings, including ECG, pulse oximeter, and both impedance and nasal thermistor pneumogram. These digitized recordings were made on a Healthdyne ${ }^{\circledR}$ system (Healthdyne Corp., Marietta, GA), which utilized an Ohmeda ${ }^{\circledR}$ Model 3740 pulse oximeter (Ohmeda Medical Systems, Madison, WI). All studies were performed in the fast response mode, such that haemoglobin oxygen saturation $\left(\mathrm{SpO}_{2}\right)$ was averaged over three seconds and the pulse interval for calculation of heart rate was averaged over five seconds. The multichannel recordings were subsequently analyzed for dysrhythmia, respiratory variation, and haemoglobin desaturation. Apnoea was defined as cessation of all nasal air flow for $10 \mathrm{sec}$, bradycardia as heart rate $<90 \mathrm{bpm}$. A hypoxic event was considered minor if the lowest $\mathrm{SpO}_{2}$ was $80-89 \%$ for a period of less than one minute; an event was considered major if the $\mathrm{SpO}_{2}$ was $<80 \%$ or if an event with $\mathrm{SpO}_{2} 80-89 \%$ persisted more than one minute. Physical stimulation and/or supplemental oxygen were given to the infant at the discretion of the bedside caregiver for apnoea or desaturation.

Infants were assessed for comfort by the bedside nurse. Pain was measured by the modified infant pain scale every four hours postoperatively and at any time discomfort was apparent. All possible side effects of morphine (e.g., sedation, apnoea, bradycardia, haemoglobin desaturation, urinary retention, vomiting, and pruritus) were also assessed and recorded by the bedside nurse.

Response to $\mathrm{CO}_{2}$ was assessed by the re-breathing technique ${ }^{15}$ with the use of a close-fitting cushion mask at the following times: prior to induction of anesthesia; on arrival to PACU prior to morphine administration; at discharge from PACU one hour after morphine administration; and on the first postoperative day, one hour after a morphine administration.

Serum morphine concentrations were determined using $1 \mathrm{ml}$ blood samples obtained prior to the initial morphine administration, and at 15, 30,60, and 120 min after morphine administration in the PACU. The blood was obtained from indwelling arterial or venous catheters through which no morphine had been administered. The samples were collected and sampled by high performance liquid chromatography (HPLC), as previously described. ${ }^{10,16}$ The method is sensitive to 1 $\mathrm{ng} \cdot \mathrm{ml}^{-1}$ with linear reproducibility over the range 1 to $500 \mathrm{ng} \cdot \mathrm{ml}^{-1}$; for determination of between-run precision on $50 \mu \mathrm{l}$ samples, control samples of 5,25 , and 100 $\mathrm{ng} \cdot \mathrm{ml}^{-1}$ showed coefficients of variation of $16.2 \%$, $8.1 \%$ and $4.1 \%$, respectively. ${ }^{16}$ Morphine concentration was analyzed by area under curve methodology to calculate clearance and the fraction of morphine available systemically after epidural administration. ${ }^{17}$

Statistical calculations were performed with SPSS for Windows (SPSS Inc., Chicago, ILL). Continuous variables measured at a single time in the three groups were compared by one way ANOVA with Tukey's adjustment for post hoc pair wise comparisons. Group differences between variables that were sampled at multiple times on each subject were analyzed with MANOVA. A paired $t$ test was used to compare the control slope of the $\mathrm{CO}_{2}$ response curve with the postoperative day 1 slope for each group. All data are presented as mean \pm S.D., and significance was defined as $P<0.05$.

\section{Results}

Eighteen infants were enrolled in this study. One additional infant who had been enrolled in Group 2 was removed from the study because placement of his caudal epidural catheter postoperatively was unsuccessful. The three groups of infants were similar in terms of postnatal age and weight, and no infant had been premature at birth (Table I). All infants underwent abdominal or genitourinary surgical procedures with general anaesthesia that included halothane or isoflurane, with or without nitrous oxide, and a neuromuscular blocking agent (pancuronium bromide or vecuronium bromide). 
TABLE I Demographic data

\begin{tabular}{llll}
\hline Treatment group & $\begin{array}{l}\text { Low dose } \\
\text { epidural }\end{array}$ & $\begin{array}{l}\text { High dose } \\
\text { epidural }\end{array}$ & Intravenous \\
\hline Age (mo) & $7.7 \pm 2.1$ & $7.7 \pm 2.0$ & $9.2 \pm 1.9$ \\
Weight (kg) & $7.6 \pm 1.2$ & $8.6 \pm 0.3$ & $8.2 \pm 1.0$ \\
Surgery duration (hr) & $5.1 \pm 1.6$ & $3.9 \pm 1.2$ & $4.8 \pm 1.0$ \\
Procedure & $2 \mathrm{D}, 4 \mathrm{U}$ & $4 \mathrm{D}, 2 \mathrm{U}$ & $4 \mathrm{D}, 2 \mathrm{U}$ \\
\hline
\end{tabular}

(D) Duhamel pull-through procedure for Hirschsprung's disease. (U) Urological procedures including: ureteral reimplantation (3), heminephrectomy \pm ureteral reimplantation (4), pyeloplasty with colostomy (1).

TABLE II Morphine administration

\begin{tabular}{llll}
\hline & $\begin{array}{l}\text { Low dose } \\
\text { epidural }\end{array}$ & $\begin{array}{l}\text { High dose } \\
\text { epidural }\end{array}$ & Intravenous \\
\hline $\begin{array}{l}\text { Interval to 2nd dose }(\mathrm{hr}) \\
\text { Interval from 2nd to 3rd dose }\end{array}$ & $7.3 \pm 3.1$ & $8.7 \pm 1.2$ & $4.0 \pm 0.8^{*}$ \\
$\quad(\mathrm{hr})$ & $6.8 \pm 2.0$ & $9.7 \pm 5.7$ & $3.7 \pm 1.3 \dagger$ \\
$\begin{array}{l}\text { Number of doses in } 1 \mathrm{st} 24 \mathrm{hr} \\
\text { Total dose in ist } 24 \mathrm{hr} .\end{array}$ & $3.8 \pm 0.8$ & $3.5 \pm 0.8$ & $6.7 \pm 1.6^{*}$ \\
$\quad\left(\mathrm{mg} \cdot \mathrm{kg}^{-1}\right)$ & $0.11 \pm 0.04$ & $0.16 \pm 0.04$ & $0.67 \pm 0.34^{*}$ \\
Dose regimen changes & $2 \uparrow$ & $2 \downarrow$ & $3 \uparrow$ \\
\hline
\end{tabular}

$* P<0.05$ Intravenous vshigh dose and vs low dose.

$+P<0.05$ Intravenous vs high dose.

TABLE III Side effects

\begin{tabular}{llll}
\hline & $\begin{array}{l}\text { Low dose } \\
\text { epidural }\end{array}$ & $\begin{array}{l}\text { High dose } \\
\text { epidural }\end{array}$ & Intravenous \\
\hline$n$ & 6 & 6 & 6 \\
\#Patients (average \# events & per affected patient) & \\
Pruritus & 5 & 4 & 4 \\
Sedation & 0 & 0 & 1 \\
Apnoea \pm bradycardia & $2(7)$ & $3(1)$ & $5(3)^{*}$ \\
Bradycardia & $1(1)$ & $3(2)$ & $1(5)$ \\
Hypoxaemic events & & & \\
- Minor & $4(3)$ & $4(2)$ & $6(3)^{*}$ \\
- Major & $1(2)$ & $4(2) \dagger$ & $2(2)^{*}$ \\
- None & 2 & 0 & 0 \\
Complications & 1 & 0 & 0 \\
Suppplementary analgesia & $2 \ddagger$ & $1 \ddagger$ & $3 \S$ \\
\hline
\end{tabular}

*Average \# events noted excludes one patient in this group with 20 apnoeic, 23 minor hypoxaemic, and 15 major hypoxaemic events (see text).

†One patient placed on supplemental oxygen after first event. $\ddagger$ Acetaminophen only.

§Acetaminophen (1), acetaminophen with codeine (1), belladona and opium suppository (1).

None of the patients had an adverse outcome. All infants had satisfactory postoperative analgesia as assessed by the modified infant pain scale. Analgesia was achieved consistently both by subjective assessment and by achievement of a pain score $>16$ within five minutes of morphine administration by either route.

The profile of morphine administration was different among the epidural groups and the intravenous group (Table II). Infants receiving intravenous morphine required the second dose administration four hours after the initial dose, compared with seven to eight hours for the infants receiving epidural morphine; the third administration in the intravenous group also occurred after a shorter interval than did the high dose epidural group $(P<0.05)$. The total number of doses and total amount of administered morphine for the first $24 \mathrm{hr}$ after surgery were greater in the intravenous group than in either of the epidural groups. Dose regimen adjustments were necessary in all three groups. Two infants in the low dose epidural group required increases, although in one case the increase in analgesic requirement was probably related to a postoperative surgical complication (described below). Two infants in the high dose epidural group required a decrease and/or termination of therapy due to severe pruritus. Infants in the intravenous group required $0.050-0.150 \mathrm{mg} \cdot \mathrm{kg}^{-1}$ for initial pain control, and three of these infants required subsequent dose increases.

Side effects of therapy were common (Table III). Pruritus occurred in infants in all three groups and usually presented with infants rubbing their eyes with their hands or rubbing their faces in the bed clothing. Treatment included diphenhydramine alone $(n=8)$ or in combination with naloxone $(n=4)$. In two patients in the high dose epidural group, as noted above, persistent pruritus despite treatment led to discontinuation of epidural therapy. In one patient in the intravenous group, discomfort caused by unrecognized pruritus was treated as pain with increasing doses of morphine; monitoring documented 20 subsequent episodes of apnoea and 38 episodes of haemoglobin desaturation $\left(\mathrm{SpO}_{2}\right.$ as low as $70 \%$ ). Excessive clinical sedation and isolated bradycardia were uncommon in any group.

Apnoea-bradycardia events, as well as minor and major hypoxaemic events, were documented by $24-\mathrm{hr}$ multi-channel recordings (Figure 3) in many of the patients. However, eight of the 18 infants had no documented apnoea and, excluding the one infant in Group 3 described above, the six infants with major hypoxaemic events had, on average, two such events per infant. Sixty percent of the apnoeic events were obstructive; 75\% of hypoxaemic events occurred without apnoea, although often with disorganized respiration; and $42 \%$ of the apnoeic events occurred without hypoxaemia. Seventy-five percent of the hypoxaemic events in the epidural groups occurred $>\mathbf{2} \mathrm{hr}$ following morphine 


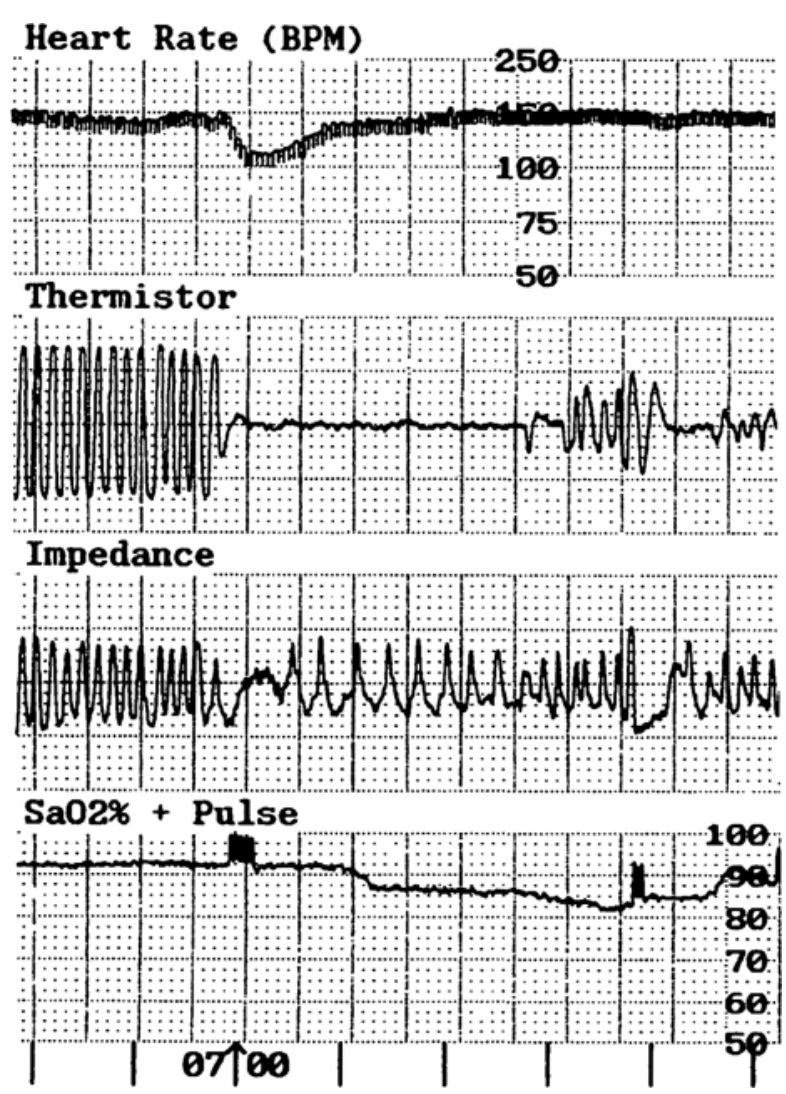

FIGURE 3 Representative tracing showing episode of obstructive apnoea marked by absent nasal air flow with chest wall impedance changes; heart rate decreased to $100 \mathrm{bpm}$ and $\mathrm{SpO}_{2}$ to $82 \%$. Each box represents five seconds.

administration, whereas $89 \%$ of such events in the intravenous group occurred $<2 \mathrm{hr}$ following morphine administration.

Other side effects included a surgical complication (intussusception following a Duhamel procedure) in one infant in the low dose epidural group, who was consequently removed from the study at the end of the first postoperative day. Supplemental analgesics during the period of study were required by at least one patient in each group, although acetaminophen alone was given in most cases. Urinary retention and nausea-vomiting could not be assessed since all patients had indwelling bladder drainage and 11 had nasogastric tubes.

Serial determination of $\mathrm{CO}_{2}$ response curve slopes demonstrated no differences among the three groups, and interpatient variability was considerable (Table IV). Preoperative unsedated response curve slopes were similar among the groups (range, $36-41 \mathrm{ml} \cdot \mathrm{min}^{-1} \cdot \mathrm{mmHg}$ $\mathrm{ETCO}_{2}{ }^{-1} \cdot \mathrm{kg}^{-1}$ ). Response curve slopes determined on postoperative day one, one hour after morphine admin-
TABLE IV Carbon dioxide response curve slopes $\left(\mathrm{ml} \cdot \mathrm{min}^{-1} \cdot \mathrm{mmHg}\right.$ $\mathrm{ETCO}_{2}^{-1} \cdot \mathrm{kg}^{-1}$ )

\begin{tabular}{llll}
\hline & $\begin{array}{l}\text { Low dose } \\
\text { epidural }\end{array}$ & $\begin{array}{l}\text { High dose } \\
\text { epidural }\end{array}$ & Intravenous \\
\hline Preoperative control & $38 \pm 9$ & $41 \pm 11$ & $36 \pm 12$ \\
PACU admission & $27 \pm 13$ & $48 \pm 34$ & $25 \pm 15$ \\
PACU departure & $28 \pm 14$ & $27 \pm 10$ & $35 \pm 12$ \\
Postoperative day 1 & $16 \pm 8$ & $27 \pm 7^{*}$ & $20 \pm 7 \dagger$ \\
\hline
\end{tabular}

$* P<0.02$ Postoperative day 1 vs control.

$\dagger P<0.004$ Postoperative day 1 vs control.

TABLE V Serum morphine concentration $\left(\mathrm{ng} \cdot \mathrm{ml}^{-1}\right)$

\begin{tabular}{llll}
$\begin{array}{l}\text { Time following morphine } \\
\text { administration } \\
(\text { min })\end{array}$ & $\begin{array}{l}\text { Low dose } \\
\text { epidural }\end{array}$ & $\begin{array}{l}\text { High dose } \\
\text { epidural }\end{array}$ & Intravenous \\
\hline 0 & 0 & 0 & 0 \\
15 & $1.3 \pm 0.9$ & $5.7 \pm 3.0^{*}$ & $8.6 \pm 2.4 \dagger$ \\
30 & $1.1 \pm 0.7$ & $7.7 \pm 7.8^{*}$ & $6.2 \pm 2.4 \dagger$ \\
60 & $1.1 \pm 0.6$ & $8.5 \pm 12.5^{*}$ & $3.4 \pm 1.0 \dagger$ \\
120 & $0.6 \pm 0.4$ & $2.7 \pm 0.9$ & $1.7 \pm 0.9$ \\
\hline
\end{tabular}

${ }^{*} P<0.055$ Low dose vs high dose at 15,30 , and $60 \mathrm{~min}$.

$\dagger P<0.0001$ Low dose vs intravenous at 15,30 , and $60 \mathrm{~min}$.

istration, were similar among the three groups. This slope was less than the preoperative slope in the high dose epidural $(P<0.02)$ and intravenous groups $(P<0.004)$. Response curve slopes did not correlate with the occurrence of apneic or desaturation events in individual infants.

Serial determinations of serum morphine concentrations demonstrated negligible concentrations in the low dose epidural group (i.e., $<2 \mathrm{ng} \cdot \mathrm{ml}^{-1}$ ) (Table V). Serum concentrations in the high dose epidural and the intravenous groups were similar and higher than those of the low dose epidural group at 15,30, and $60 \mathrm{~min}$. Only one patient had serum concentrations of morphine $>15$ $\mathrm{ng} \cdot \mathrm{ml}^{-1}$, a patient in the high dose epidural group with a concentration of $23.3 \mathrm{ng} \cdot \mathrm{ml}^{-1}$ at $30 \mathrm{~min}$ and $34 \mathrm{ng} \cdot \mathrm{ml}^{-1}$ at $60 \mathrm{~min}$ after administration. The clearances estimated for the intravenous group $\left(19.8 \pm 5.9 \mathrm{ml} \cdot \mathrm{min}^{-1} \cdot \mathrm{kg}^{-1}\right)$ and for the high dose epidural group (59.4 \pm . 3.2 $\mathrm{ml} \cdot \mathrm{min}^{-1} \cdot \mathrm{kg}^{-1}$ ) yield a systemic availability for morphine of 0.33 after epidural administration.

\section{Discussion}

This study has demonstrated that, in infants undergoing abdominal and genitourinary surgery, all three morphine regimens provided rapid and effective postoperative analgesia, as assessed by a modified infant pain scale, with minimal need for supplementary medications. Epidural morphine had the advantage of providing satis- 
factory analgesia with fewer administrations and less total morphine administered in the first postoperative day, and bolus epidural morphine, $0.025 \mathrm{mg} \cdot \mathrm{kg}^{-1}$ appeared to be an effective starting dose in several patients. Pruritus and some degree of cardiorespiratory compromise (apnoea, bradycardia, haemoglobin desaturation, and depression of $\mathrm{CO}_{2}$ response) occurred in many of the infants receiving either epidural or intravenous bolus morphine.

Several previous reports including both infants and children have established the effectiveness of epidural morphine $0.050-0.070 \mathrm{mg} \cdot \mathrm{kg}^{-1}$ in the control of postoperative pain, ${ }^{6,8,18.19}$ although these reports made no attempt to determine the optimal dose or to compare epidural with other routes of administration. The higher doses utilized in these studies provided longer duration of analgesia (mean duration $>10 \mathrm{hr}$ ) than we found in our epidural groups (mean 7-8 hr) and were associated with serious side effects: excessive sedation $(0-4 \%)$; respiratory depression $(0-8 \%)$, especially in infants who received intravenous opioids intraoperatively; ${ }^{6,8}$ nausea and vomiting $(0-31 \%)$; urinary retention $(7-50 \%)$; and pruritus (3-88\%). The variability in reported side effects may reflect both the difficulty in their ascertainment in infants generally and the different methods of assessment utilized in these reports.

Apnoea occurred in 10 of 18 infants and hypoxaemic events occurred in 16 of 18 in this study, although the number of events for most of the infants was small. This represents a higher frequency of respiratory events than previously reported for a population of healthy non-surgical infants older than two months, ${ }^{20}$ for infants receiving epidural morphine, ${ }^{6,18,19}$ and for older children receiving postoperative morphine analgesia. ${ }^{21}$ The high frequency of apnoea and desaturation seen here probably reflects the detailed method of ascertainment. That the majority of apnoeic events were obstructive indicates that they would not have been detected by chest wall impedance alone. That the majority of hypoxaemic events occurred without apnoea indicates that they would not have been detected by respiratory monitoring without pulse oximetry. Although specific apnoeic and hypoxaemic events were not correlated with serum concentrations of morphine, the timing of the majority of hypoxaemic events $(<2 \mathrm{hr}$ following bolus intravenous and $>2 \mathrm{hr}$ following bolus epidural morphine) is consistent with their occurring at peak morphine effect at central nervous system receptors. ${ }^{22}$

Severe pruritus was seen in 13 of 18 infants in this study, a finding consistent with that of Dalens et al. ${ }^{18}$ The difficulty in diagnosing pruritus in infants is illustrated by the patient in Group 3 whose agitation from pruritus was interpreted as pain by experienced nurses and was treated with frequent administrations of intravenous morphine for discomfort. The multiple episodes of apnoea and haemoglobin desaturation that followed morphine administration in this patient indicate the potential impact of such misdiagnosis. In addition, treatment of pruritus with antihistamines and other medications may increase the risk of excessive sedation and other side effects of morphine.

The rapid onset of analgesia after administration of bolus epidural morphine in infants has not been previously reported. Attia et al. ${ }^{\prime}$ found that the onset of analgesia in children 2 to $15 \mathrm{yr}$ old after epidural morphine $0.050 \mathrm{mg} \cdot \mathrm{kg}^{-1}$ occurred at a mean of $30 \mathrm{~min}$. The negligible serum morphine concentrations at all times after low dose epidural morphine suggest that its immediate effect is not mediated by systemic absorption of the opioid. The rapid onset of effect in infants is important to note because it may render unnecessary the concomitant administration of potent opioids like fentanyl by intravenous or epidural routes to establish immediate analgesia.

Measured $\mathrm{CO}_{2}$ response slopes at preoperative baseline were similar to those previously reported in infants ${ }^{15,23-25}$ and showed depression after morphine administration on postoperative day 1 in most infants. The method of slope determination utilized a close-fitting mask which stimulates the infant, and this stimulation may explain the wide variability in the $\mathrm{CO}_{2}$ response slopes obtained at the different times. Slopes obtained in individual infants were not predictive of side effects of morphine.

Serum morphine concentrations obtained were generally lower than previous published data. In seven children 2-15 yr of age who received epidural morphine $0.050 \mathrm{mg} \cdot \mathrm{kg}^{-1}$, Attia et al. ${ }^{1}$ found peak serum concentrations of $26.7 \pm 9.1 \mathrm{ng} \cdot \mathrm{ml}^{-1}$ (range, 13.1-39) at $10.3 \pm$ $0.3 \mathrm{~min}$ (range, 10.0-10.7) after injection, while only one patient in our study had peak levels $>15 \mathrm{ng} \cdot \mathrm{ml}^{-1}$. The higher serum concentrations after epidural administration may reflect a smaller volume of distribution in children than in infants; our short period of sampling does not allow calculation of this volume. The serum concentrations $>15 \mathrm{ng} \cdot \mathrm{ml}^{-1}$ in one infant in Group 2 may reflect variability of absorption or delayed systemic absorption after an epidural injection of morphine that was partially intravascular. The clearance of morphine calculated for those infants receiving intravenous morphine (i.e., $19.8 \mathrm{ml} \cdot \mathrm{min}^{-1} \cdot \mathrm{kg}^{-1}$ ) is consistent with previous reports; ${ }^{26,27}$ the clearance for those receiving epidural morphine (i.e., $59.4 \mathrm{ml} \cdot \mathrm{min}^{-1} \cdot \mathrm{kg}^{-1}$ ) is greater than twice that reported in adults. ${ }^{28}$

In summary, we have shown in 18 infants that effective postoperative analgesia was provided by bolus mor- 
phine given either epidurally in two doses or intravenously, although there was no difference in safety or efficacy among the groups. Investigation of a larger number of infants might establish a correlation between morphine dose, route of administration, and incidence of side effects. Extrapolation of data from other infant populations monitored less intensively ${ }^{8,29}$ indicates that $>400$ infants would have to be studied in order to establish a $10 \%$ reduction (with $95 \%$ confidence) in postoperative apnoea by one of three treatments. Our investigation indicates that pruritus, apnoea and haemoglobin desaturation occur in many infants to whom morphine is repeatedly administered intravenously or epidurally for the control of postoperative pain after major abdominal or genitourinary surgery. Although the long term consequence of desaturation events is unclear, it does seem appropriate to carefully observe this group of infants with continuous pulse oximetry.

\section{Acknowledgements}

The authors are indebted to Gail Anderson, Ph.D., for assistance in determinations of morphine clearance; Mark Scott for assistance in obtaining and analyzing multi-channel recordings; Nikki Louis and Kim Louis for assistance in preparation of the manuscript; and the surgical ward nurses at Children's Hospital and Medical Center for assistance and cooperation in carrying out this study.

\section{References}

1 Attia J, Ecoffey C, Sandouk P, Gross JB, Samii K. Epidural morphine in children; pharmacokinectics and $\mathrm{CO}_{2}$ sensitivity. Anesthesiology 1986; 65: 590-4.

2 Haberkern CM, Tyler DC, Krane EJ. Postoperative pain management in children. Mt Sinai J Med 1991; 58: 247-56.

3 Glenski JA, Warner MA, Dawson B, Kaufman B. Postoperative use of epidurally administered morphine in children and adolescents. Mayo Clin Proc 1984; 59: 530-3.

4 Krane EJ, Jacobson LE, Lynn AM, Parrot C, Tyler DC. Caudal morphine for postoperative analgesia in children: a comparison with caudal bupivacaine and intravenous morphine. Anesth Analg 1987; 66: 647-53.

5 Krane EJ, Tyler DC, Jacobson LE. The dose response of caudal morphine in children. Anesthesiology 1989; 71: 48-52.

6 Rasch DK, Webster DE, Pollard TG, Gurkowski MA. Lumbar and thoracic epidural analgesia via the caudal approach for postoperative pain relief in infants and children. Can J Anaesth 1990; 37: 359-62.

7 Rosen $K R$, Rosen DA. Caudal epidural morphine for control of pain following open heart surgery in children. Anesthesiology 1989; 70: 418-21.
8 Valley RD, Bailey $A G$. Caudal morphine for postoperative analgesia in infants and children: a report of 138 cases. Anesth Analg 1991; 72: 120-4.

9 Bhat $R$, Chari $G$, Gulati A, Aldana $O$, Velamati $R$, Bhargava $H$. Pharmacokinetics of a single dose of morphine in preterm infants during the first week of life. $J$ Pediatr 1990; 117: 477-81.

10 Lynn AM, Slattery JT. Morphine pharmacokinetics in early infancy. Anesthesiology 1987; 66: 136-9.

11 Meistelman C, Benhamou D, Barre J, et al. Effects of age on plasma protein binding of sufentanil. Anesthesiology 1990; 72: 470-3.

12 Way WL, Costley EC, Way EL. Respiratory sensitivity of the newborn infant to meperidine and morphine. Clin Pharmacol Ther 1964; 6: 454-61.

13 Barrier G, Attia J, Mayer MN, Amiel-Tison C, Shnider SM. Measurement of post-operative pain and narcotic administration in infants using a new clinical scoring system. Intensive Care Med 1989; 15: S37-9.

14 Grunau RVE, Craig KD. Facial activity as a measure of neonatal pain expression. Advances in Pain Research Therapy 1990; 15: 147-55.

15 Lynn AM, Nespeca MK, Opheim KE, Slattery JT. Respiratory effects of intravenous morphine infusions in neonates, infants, and children after cardiac surgery. Anesth Analg 1993; 77: 695-701.

16 Lynn AM, Opheim KE, Tyler DC. Morphine infusion after pediatric cardiac surgery. Crit Care Med 1984; 12: 863-7.

17 Gibaldi M, Perrier D. Pharmacokinetics, 2nd ed. New York: Marcel Dekker, 1982: 319-53.

18 Dalens B, Tanguy A, Haberer J-P. Lumbar epidural anesthesia for operative and postoperative pain relief in infants and young children. Anesth Analg 1986; 65: 1069-73.

19 Serlin $S$. Single-dose caudal epidural morphine in children: safe, effective, and easy. J Clin Anesth 1991; 3: 386-90.

20 Hoppenbrouwers T, Hodgman JE, Harper RM, Hoffman E, Sterman MB, McGinty DJ. Polygraphic studies of normal infants during the first six months of life: III. Incidence of apnea and periodic breathing. Pediatrics 1977; 60: 418-25.

21 Tyler DC, Woodham M, Stocks J, Leary A, Lloyd-Thomas $A$. Oxygen saturation in children in the postoperative period. Anesth Analg 1995; 80: 14-9.

$22 \mathrm{Hug}$ CC Jr. Pharmacokinetics and dynamics of narcotic analgesics. In: Prys-Roberts C, Hug CC Jr (Eds.). Pharmacokinetics of Anaesthesia. Oxford: Blackwell Scientific Publications, 1984: 187-234.

23 Avery ME, Chernick V, Dutton RE, Permutt S. Ventilatory response to inspired carbon dioxide in infants and adults. J Appl Physiol 1963; 18: 895-903.

24 Olsen $G D$, Lees $M H$. Ventilatory response to carbon diox- 
ide of infants following chronic prenatal methadone exposure. J Pediatr 1980; 96: 983-9.

25 Nichols DG, Yaster M, Lynn AM, et al. Disposition and respiratory effects of intrathecal morphine in children. Anesthesiology 1993; 79: 733-8.

26 McRorie TI, Lynn AM, Nespeca MK, Opheim KE, Slattery $J T$. The maturation of morphine clearance and metabolism. American Journal of Diseases of Children 1992; 146: 972-6.

27 Pokela M-L, Olkkola KT, Seppälä T, Koivisto M. Agerelated morphine kinetics in infants. Dev Pharmacol Ther 1993; 20: 26-34.

28 Zakowski MI, Ramanathan S, Turndorf H. A two-dose epidural morphine regimen in cesarean section patients: pharmacokinetic profile. Acta Anaesthesiol Scand 1993;37:584-9.

29 Coté CJ, Zaslavsky A, Downes JJ, et al. Postoperative apnea in former preterm infants after inguinal herniorrhaphy. Anesthesiology 1995; 82: 809-22. 